
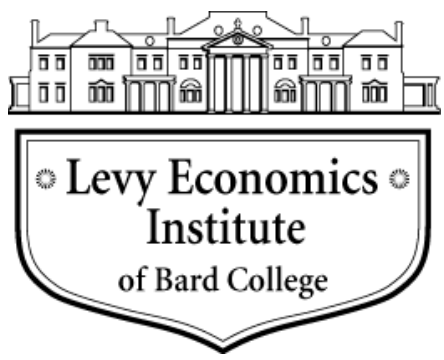

Working Paper No. 924

\title{
Induced Shifting Involvements and Cycles of Growth and Distribution
}

by

\author{
Michalis Nikiforos* \\ Levy Economics Institute of Bard College
}

February 2019

*For useful discussions, comments, and suggestions, I would like to thank Duncan Foley, Orsola Constantini, Leila Davis, Giorgos Galanis, John Henry, Tom Michl, Gil Skillman, Peter Skott, and Roberto Veneziani, as well as participants in the Analytical Political Economy workshop at Queen Mary University, London, the 44th EEA annual conference in New York, the 21th FMM conference in Berlin, the 16th World Congress of Social Economics at Colorado State University, and the 2019 Annual Meeting of the American Economic Association in Atlanta. The usual disclaimer applies.

The Levy Economics Institute Working Paper Collection presents research in progress by Levy Institute scholars and conference participants. The purpose of the series is to disseminate ideas to and elicit comments from academics and professionals.

Levy Economics Institute of Bard College, founded in 1986, is a nonprofit, nonpartisan, independently funded research organization devoted to public service. Through scholarship and economic research it generates viable, effective public policy responses to important economic problems that profoundly affect the quality of life in the United States and abroad.

\author{
Levy Economics Institute \\ P.O. Box 5000 \\ Annandale-on-Hudson, NY 12504-5000 \\ http://www.levyinstitute.org
}

Copyright (C) Levy Economics Institute 2019 All rights reserved

ISSN 1547-366X 


\begin{abstract}
The paper builds on the concept of (shifting) involvements, originally proposed by Albert Hirschman (2002 [1982]). However, unlike Hirschman, the concept is framed in class terms. A model is presented where income distribution is determined by the involvement of the two classes, capitalists and workers. Higher involvement by capitalists and lower involvement by workers tends to increase the profit share and vice versa. In turn, shifts in involvements are induced by the potential effect of a change in distribution on economic activity and past levels of distribution. On the other hand, as the profit share increases, the economy tends to become more wage led. The dynamics of the resulting model are interesting. The more the two classes prioritize the increase of their income share over economic activity, the more possible it is that the economy is unstable. Under the stable configuration, the most likely outcome is Polanyian predator-prey cycles, which can explain some interesting historical episodes during the 20th century. Finally, the paper discusses the possibility of conflict and cooperation within each of the distribution-led regimes.
\end{abstract}

KEYWORDS: Shifting Involvements; Hirschman; Wage Led; Profit Led; Predator-Prey

JEL CLASSIFICATIONS: E11; E12; E21; E22; E32 


\section{INTRODUCTION}

In December 2017, the US Congress voted on, and then President Trump signed into law, the Tax Cuts and Jobs Act. From a political economy point of view, this is an extraordinary piece of legislation. After seven years of austerity, it introduced tax cuts of $\$ 2$ trillion over a period of ten years. ${ }^{1}$ Its benefits were heavily skewed toward the top income brackets from day one. By 2027 , as many of the provisions of the law will phase out, households in the bottom two quintiles will end up paying a slightly higher tax rate. At the same time, only the households in the top quintile will pay less taxes (Tax Policy Center 2017). Moreover, by repealing the individual mandate of the Affordable Care Act of 2010 — and essentially terminating the subsidies to poor households who could not afford to buy insurance-the new law makes the households in the bottom quintile worse off from day one (Congressional Budget Office 2017).

These tax changes are the capstone of four decades of increasing income inequality (Piketty 2014; Galbraith 2012; Wolff 2017), and they emphasize the potentially explosive trajectory of income distribution. To use Myrdal's (1957) terminology, there is a circular cumulative causation: as corporations and households at the top have become richer, they have been more able to further tilt distribution in their favor. On the opposite side, as labor has become weaker, it was less and less in a position to prevent a further deterioration in its share of income.

The increase in income inequality in the last four decades resembles the period before the mid-1930s, which was also marked by a continuous increase in income inequality (Kuznets 1955; Piketty and Saez 2003; Alvaredo et al. 2016). At the same time, it comes in stark contrast with the the period in between - the mid-1930s to the late 1970s. Over that period, inequality decreased or

\footnotetext{
${ }^{1}$ As of the third quarter of 2018, the current business cycle is the only one in the postwar history of the US economy with negative growth in government expenditure compared to its trough in the second quarter of 2009. This prolonged austerity that commenced with the Budget Control Act of 2011 has been one of the major reasons for the slow recovery of the last decade - what many people have interpreted as secular stagnation. For a discussion, see Nikiforos and Zezza $(2017,2018)$.
} 
remained stable and workers were able to achieve significant advancements in their living standards, in terms of increasing wages, improvements in social security, the establishment of Medicare, etc. These achievements were promoted by a relatively strong and robust labor movement. Over the same period, there were also a series of other movements, like the Civil Rights movement, the antiwar movement, and the "public interest" movement, that were able to promote workplace equality, consumer protection, and environmental regulation. An interesting question then is: How can we explain these fluctuations in the distribution of income?

An also interesting related stylized fact is that the changes in the direction of income distribution were preceded by a major crisis. The Great Depression antedated the decrease in inequality in the 1930s. The increase in inequality of the last four decades was preceded by the economic crisis and stagnation of the 1970 s.

The fluctuations in income distribution were accompanied by fluctuations in the engagement of the public and businesses. As it was mentioned above, the period of decreasing inequality was marked by strong public movements, while at the same time businesses were relatively disengaged from the political process. This situation was reversed in the 1970s and the period that followed, which was marked by a decline in public and labor activism, while at the same time businesses and households in the top income brackets became more active.

The decline in public and labor activism and the indifference about income inequality has started to slowly change recently. The years after the crisis of 2007-9 have seen several political movements and other developments, centered around economic stagnation and income inequality, which would have been very surprising until recently. In the aftermath of the crisis, the main motto of the Occupy Wall Street movement was "We are the 99 percent," a direct reference to studies of inequality. The issues of employment, stagnation, and income inequality are becoming central in the political discourse. Many politicians, some of them self-proclaimed socialists (a 
forbidden word in American politics) who were until recently in the fringe of the political spectrum, are becoming increasingly popular because they base their campaigns on these issues. Even the popularity of Thomas Piketty's Capital in the Twenty-First Century is a manifestation of the increasing awareness of these issues (media in the United States were baffled how a 700-page tome full of words like "disequilibria" and "Ricardian" could be at the top of the best-sellers list).

It is thus an interesting endeavor to try to explain these facts: fluctuations in distribution; crises as precursors of the tipping points of distribution; fluctuations in engagements; and the recent mobilizations. A good starting point for this discussion is Albert Hirschman's Shifting Involvements: Private Interest and Public Action (2002 [1982]). Hirschman tried to explain the rapid transition between the social movements of the late 1960 s to citizens retreating to a more atomistic behavior only ten years later. He provides an explanation in terms of a representative “consumer-citizen," who derives utility from public action and consuming private goods. Hirschman argues that the actual utility from either choice is always lower than what is expected. This leads to endogenous oscillations in the involvements between the two states of private interests and public action.

However, by framing his theory in terms of a representative consumer-citizen, Hirschman cannot explain shifts in the distribution of income, or how concerns about income distribution contribute to the shift in involvements. In the present paper, Hirschman's concept of involvement is kept, but is now applied to the involvement of the two classes: workers and capitalist. The distribution of income between wages and profits is the result of the level of involvement of the classes. Higher capital involvement or lower labor involvement leads to a higher profit share and vice versa.

The question then is what causes the shifts in involvements. We can distinguish three major factors. First, as the income share of each class increases, the class will target an even-higher share of income and that will lead-ceteris paribus - to a shift in its involvement in order to achieve it. 
Second, involvement carries a cost, so a shift in involvement is deterred by its respective marginal cost. Because of increasing returns, the marginal cost of involvement is a negative function of the income share. These two factors are destabilizing, as the change in the profit share becomes a positive function of its level.

Finally, the shifts in involvements are affected by the potential effect of a change in distribution on economic activity. The argument is stated in terms of a simple Kaleckian-Structuralist model of growth and distribution; therefore this effect is related to whether the economy is wage or profit led. Hence this factor is captured by what we call "wage-ledness" of the economy-the difference between the propensity to save and the propensity to invest out of profits. As the wage-ledness increases, the involvement of capitalists will tend to decrease and the involvement of workers will tend to increase. As a result of the aforementioned factors, the increase in the involvement of capitalists and the decrease in the involvement of workers (and therefore the increase in the profit share) is a positive function of the profit share and a negative function of the wage-ledness of the economy.

On the other hand, the economy will tend to become more wage led as the profit share increases because the propensity to save out of the profit share increases while the propensity to invest decreases. These kinds of changes in the propensities to invest and save are intuitive and documented in the literature, but are usually ignored in the neo-Kaleckian literature. For example, it is well-documented in the literature that investment was very tightly linked to profit flows in the 1970s, but there has been a gradual decoupling of the two over the last decades. The aforementioned recent corporate tax cuts have had a very small effect on investment, if any at all.

The resulting system has some interesting dynamic properties. One possibility is that the unstable dynamics of distribution dominate. This is the case when the two classes press for further increases in their share of income irrespective of its effect on economic activity. On the other hand, 
when the effect on economic activity is taken into consideration, and the feedback effect of the profit share on "distribution-ledness" is strong, the system follows counterclockwise cycles in the $<$ profit share, wage-ledness $>$ space. These are essentially predator-prey dynamics (Lotka 1910; Volterra 1931; Goodwin 1967), where distribution is the prey and distribution-ledness (and thus indirectly growth) is the predator. These dynamics are also related to the concept of the double movement, introduced by Karl Polanyi in his Great Transformation (2001 [1944]). The Polanyian element here is the reaction of involvements to wage-ledness. When the profit or wage share increase too much, there is a crisis that induces a reaction in the form of shifting involvements.

This Polanyian predator-prey framework is an interesting way to approach the long-run dynamics of the US economy during the 20th century. The high concentration of income in the 1920s was a basic reason for the Great Depression, which then led to the emergence of the New Deal institutions, which changed the direction of income distribution and created the basis for the prosperity of the early decades after WWII. However, in turn, these institutions endogenously led to the crisis of the 1970s - the shift in involvements - and the emergence of neoliberalism as a response. The neoliberal institutions exhausted their potential leading to the crisis of 2007-9 and the stagnation that has followed; the recent mobilizations can be understood as the first reaction against this.

Finally, the subdivision of wage- and profit-led regimes into cooperative and conflictual subregimes is discussed. In the cyclical configuration of the model, the economy will endogenously shift not only between wage- and profit-led periods, but also between conflictual and cooperative. From that point of view the model provides a link between what Bhaduri and Marglin (1990) call the "economic basis of contesting political ideologies," shifting involvements, and cycles of growth and distribution. 


\section{THE MACROECONOMIC STRUCTURE}

The macro structure of the model follows a simple version of the Kaleckian-Structuralist model of growth and distribution (Steindl 1952; Rowthorn 1981; Taylor 1983, 2004; Dutt 1984; Amadeo 1986; Marglin and Bhaduri 1990; Kurz 1990), assuming a closed economy without a government sector. At any given point in time, distribution of income is assumed to be constant; therefore the macro structure of the economy is fully described by the investment and saving functions. We assume a generic investment function:

$$
g^{i}=g^{i}[r(\pi, u)]=g^{i}(\pi, u)
$$

where $g^{i}$ is investment normalized for the capital stock, $r$ is the profit rate, $\pi$ is the profit share, and $u$ is the rate of capacity utilization. The effect of profitability and utilization on investment are positive, hence $g_{\pi}^{i}>0$ and $g_{u}^{i}>0$ (the subscript denotes the partial derivative for this variable).

The saving function is:

$$
g^{s}=g^{s}(\pi, u)
$$

where $g^{s}$ is total saving normalized for the capital stock. Higher income leads-ceteris paribus - to higher savings $\left(g_{u}^{s}>0\right)$; a higher profit share also leads to higher savings (and $g_{\pi}^{s}>0$ ), since capitalists' saving rate is higher than workers'.

At equilibrium, investment is equal to saving: $g^{i}=g^{s}$. Based on this identity, and solving for $u$, we can define a demand function, $u=D(\pi)$. The effect of a change in distribution on utilization is:

$$
d u / d \pi=D^{\prime}(\pi)=\frac{g_{\pi}^{i}-g_{\pi}^{s}}{g_{u}^{s}-g_{u}^{i}}
$$


Assuming that the so-called Keynesian stability condition holds $\left(g_{u}^{s}-g_{u}^{i}>0\right)$, the effect of a change in distribution depends on $g_{\pi}^{i}-g_{\pi}^{s}$. The economy is said to be profit led when an increase in the profit share leads to an increase in the utilization rate $(d u / d \pi>0)$. The sufficient condition for this is that the propensity to invest out of profits is higher than the propensity to save $\left(g_{\pi}^{i}-g_{\pi}^{s}>0\right)$. In the opposite case (when $\left.g_{\pi}^{i}-g_{\pi}^{s}<0\right)$, demand is wage led $(d u / d \pi<0)$.

We can define $\lambda=-D^{\prime}(\pi)=\frac{g_{\pi}^{s}-g_{\pi}^{i}}{g_{u}^{s}-g_{u}^{i}}$ as the degree of wage-ledness of the economy. A positive $\lambda$ means that the economy is wage led; the higher is the value of $\lambda$, the more wage led the economy is, and the stronger the response of utilization to a decrease in the profit share will be. On the other hand, the more negative $\lambda$ is, the more profit led the economy will be.

\section{SHIFTING INVOLVEMENTS}

One of the most interesting theories of long swings is put forward by Hirschman (2002 [1982]), where he tries to explain what had caused the shift from the massive social movements of the late 1960s to the withdrawal to the private sphere fifteen years later; in other words, what had caused the shifting involvements from public action to the private interest of the time he was writing the book.

Hirschman frames his theory in terms of an expected-utility-maximizing "consumer-citizen" who derives utility from public action—-the "meaningful participation in public affairs" (67)_and private consumption. Disappointment of expectations has a central role. The actual utility derived from private consumption is lower than what the individual had expected and that induces them to seek satisfaction in public action. In turn, actual utility from public action will also undershoot expectations and lead back to the pursuit of private interest. In that way there is an endogenous shift in involvements between private interest and public action. 
Because the argument is stated in terms of a representative agent, it is unable to explain long-run variations in the distribution of income or what the role of the distribution in the shift of involvements is. However, the concept of involvements remains interesting and one could utilize and extend it to arrive at a long-run theory of distribution of income between labor and capital.

\section{CLASS INVOLVEMENTS AND INCOME DISTRIBUTION}

Classical political economy emphasizes social norms, institutions, and the class struggle as the main determinants of the distribution of income. At a more concrete level, these factors are related to and determined by the collective agency, engagement, organization, and activism-in other words, the involvement — of the two classes. Hence, distribution of income is to a large extent determined by the involvement of the two classes. Historically, in the late 18th century and during the 19th century, the emergence of a capitalist class as the dominant class was the result of the active involvement of the capitalist class and its allies (Hobsbawm 1996 [1962], 1996 [1975]). More recently, the increasing dominance of capital has also been the result of the active involvement of the capitalist class in the United States and elsewhere. Similarly, the working class was able to claim an increasing share of income only after its own active involvement. Not coincidentally, a reduction in the income shares of each class is historically associated with periods of relative decreases in its involvement. The following sections provide some historical evidence for labor's and capital's involvement in the United States over the last century.

\subsection{Labor Involvement}

An obvious proxy for the involvement of the working class is union membership. Figure 1 presents data for union membership as well as income share for the top 10 percent of income earners for the years 1917 to 2014. The graph shows a clear inverse relationship between these 
Figure 1: Union Membership and Share of Income Going to the Top 10 Percent, 1917-2014

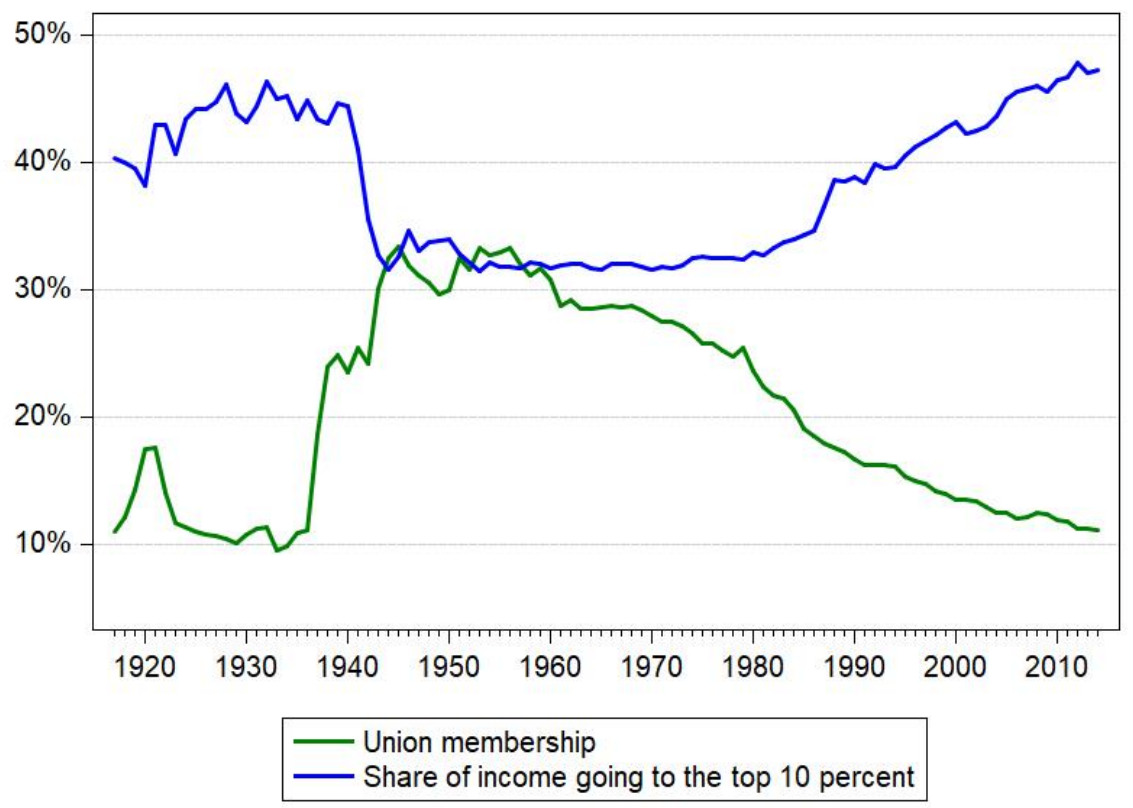

Sources: Hirsch and Macpherson (2003) and Alvaredo et al. (2016).

two variables. The decrease in income inequality during the 1930 s is associated with—or to be more precise, is preceded by-an increase in union membership. The stability of the income share in the postwar period is also associated with the relative stability of union membership. During this period, unions were able to record significant gains, like the amendments to Social Security in the 1950s and the introduction of Medicare in 1965; despite some differences, they were also an important ally for the Civil Rights movement. Finally, the increase in income inequality of the past four decades was preceded and then accompanied by a decrease in union membership. In other words, figure 1 shows a strong correlation between union membership and inequality and also some evidence of (Granger) causality running from the former to the latter.

Several other studies confirm the importance of the involvement of workers for distribution. Cohen (1991), in Making a New Deal, provides a case study for the workers in Chicago in the 1920s and 1930s, which reflects a broader national story. She argues convincingly that a large part 
of the New Deal was, to a large extent, made through political and collective responses by workers. In particular, during the 1930s, through their trade unions-mostly through the newly formed Congress of Industrial Organizations (CIO)—workers were able to wage a successful campaign that led to the recognition of the unions by the big corporations and to a series of important gains for the workers.

Ferguson (1995) puts forward what he calls the "investment theory of party competition," where investor blocks - mostly alliances of powerful industries and rich donors - are the fundamental determinant of the political outcomes in the United States. Ferguson emphasizes the importance of the "labor constraint," which conditions the range of influence of the industries' investor blocks and is an important investor block in its own right. This labor constraint was much more binding during the New Deal and the early postwar period, and has been continually relaxing over the last four decades.

Various empirical articles have also found a significant negative effect for union membership on income inequality. Card (1996, 2001), DiNardo, Fortin, and Lemieux (1996), and Firpo, Fortin, and Lemieux (2009) find that union density has a significant negative effect on wage inequality, especially for men. Farber (2005) finds that unions exert a negative effect on wage inequality through their upward pressure on the wages of nonunionized workers. Abowd (1989), DiNardo and Hallock (2002), and Lee and Mas (2012) find negative effects of unionization and union activity on the stock market returns of firms and, hence, on income inequality. Leighley and Nagler (2007) find that unions can affect distribution through their role in voter turnaround. Finally, Farber et al. (2018), using some newly available data sources that contain information on union membership — mainly Gallup public opinion polls—-find that union density has a significant negative effect on all the standard measures of income inequality (skill premium, the 90/10 ratio, the Gini coefficient, and the top-ten-percent income share). 
As forms of labor involvement we can also include movements and organizations that go beyond organized labor; in fact, some of these have often been suspicious of organized labor. In the United States, they reached their apogee in the late 1960s and early 1970s in several forms. The most famous and widely portrayed ones were the Civil Rights, the student, and the antiwar movements, which mobilized hundreds of thousands of people. All of these movements were very critical of large corporations, supported the goal of an egalitarian society, and recorded significant victories. To get an idea of how different things were compared to the recent decades, as Vogel (1989, 54-58, 98-9) writes, the vast majority of college students—even in the elite universities—had a negative opinion of corporations; according to opinion polls, half of the students polled did not want to work for corporations after their studies. In second half of the 1960s, overall university enrollment increased three times as fast as the enrollment in business schools.

Another related form of involvement at the time was through public-interest organizations. According to Vogel $(1989,94)$, close to 80 percent of the public-interest groups that had offices in Washington in the late 1970 s had been founded within the previous two decades. ${ }^{2}$ The most common target of these groups was large corporations and the influence they had on the government. Public-interest groups were very effective in influencing policy and played a crucial role in the adoption of many landmark legislative pieces related to consumer and environmental protection. They also offered a vehicle for involvement for the aforementioned disenchanted young graduates, who opted to work for them at a low salary rather than taking a well-paid private sector job.

Recent years, especially after the crisis of 2007, have seen an increase in labor involvement in various forms. Some have been trade union-related actions, like the teachers' strikes that took place in several states in the last couple of years. However, many others were not. In this latter

${ }^{2}$ Some of the most important of these groups were Ralph Nader's Center for Responsive Law and several environmental organizations. 
category we can include the the "Occupy Wall Street" movement or the participation of thousands of people in electoral campaigns of politicians who until very recently belonged to the fringe of the political spectrum. Recent growing criticisms against the monopoly practices of tech giants, and to some extent the modern Civil Rights and feminist movements (like the "Black Lives Matter" and "\#MeToo" movements), move in the same direction.

\subsection{Capital Involvement}

When it comes to capitalists, there is historical evidence that allows us to establish an important positive correlation between their involvement and income inequality. Phillips-Fein (2009, ch. 1) writes that the main opposition to the New Deal was mounted by the National Association of Manufacturers (NAM). However, in the first years of the Great Depression the membership of the NAM decreased at a fast rate-its membership in 1933 was 70 percent below its level a few years earlier-hence, the opposition proved ineffective. Another related effort of the same period was the American Liberty League. It was organized by the DuPont family and argued that the New Deal policies were moving the United States toward totalitarianism. This argument—which is today commonplace - failed to gain any traction and only attracted a few members, all of them very wealthy individuals. ${ }^{3}$

The subsequent decades saw the slow development of conservative and business-friendly networks. These networks supported cultural endeavors (like the publication of Ayn Rand's Atlas Shrugged in 1957) and the publication of magazines (National Review was founded in 1955). In 1947, the Mont Pelerin Society (MPS) was founded to fight the battle of ideas against corporatism

\footnotetext{
${ }^{3}$ It is important to note that although the business attitude toward the New Deal was generally hostile, there were corporations or business networks that were embracing the economic policies of the period. For example, the Committee for Economic Development, formed in 1942 and consisting mostly of business figures, was cautiously supportive of fiscal policy that would target full employment, and that included social programs and progressive taxation (Costantini 2018). This kind of support can be understood within the model that is built in the following section. Two other important factors that determined different businesses' degree of support for the New Deal were the weight of wages in their overall wage structure and their attitudes to trade openness (Ferguson 1995, ch.2).
} 
and the welfare state, which would lead to "serfdom." Among its founding members is the holy trinity of free market economists: Friedrich Hayek, Ludwig von Mises, and Milton Friedman. The MPS would provide the blueprint for the various conservative think tanks that mushroomed later. Finally, around the same time there are the first serious efforts to connect conservative economic ideas to religious groups.

These events were important as a basis for subsequent developments. However, to turn the tide-manifested in figure 1 with the structural break of the income share of the top 10 percent in the late 1970s-it took what Phillips-Fein (2009, ch. 9) calls the "business activist movement" of the 1970s. That decade saw many parallel rapid developments in that direction. One of these was the increase in corporate political activity. As Vogel (1989, ch. 8) writes, between 1968 and 1978, the number of corporations with public affairs offices in Washington quintupled from 100 to more than 500, with the size of the typical office increasing from one or two individuals to six or seven. In parallel, the lobbying efforts of the firms intensified. The number of firms with lobbyists increased from 175 in 1971, to 650 in 1979, and 2,445 in 1982.

In 1972, the Business Roundtable was created. It was a lobbying organization that consisted of the CEOs of the largest corporations and played an increasingly assertive role in the events of that period. In the late 1970s, all major US corporations participated in the Roundtable.

Besides the large corporations, there was an increase in the involvement of small enterprises. The National Federation of Independent Business’s membership increased from 300 to 600,000 between 1970 and 1979. At the same time, the US Chamber of Commerce was reinvigorated. Its membership increased from 36,000 in 1967 to more than 160,000 in 1980. Its congressional action committees - committees consisted of a few businessmen who lobbied their local congressman — doubled. In 1978, the Chamber created a grassroots organization, called Citizen's Choice, to “defend capitalism and free enterprise.” Its membership was 76,000 members in 1981. 
Figure 2: Number of Political Action Committees (PACs) by Type

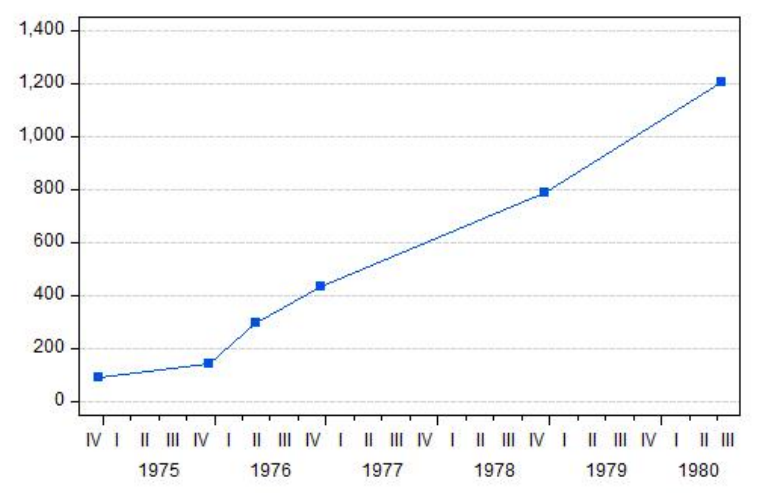

(a) Corporate PACs, December 1974-July 1980

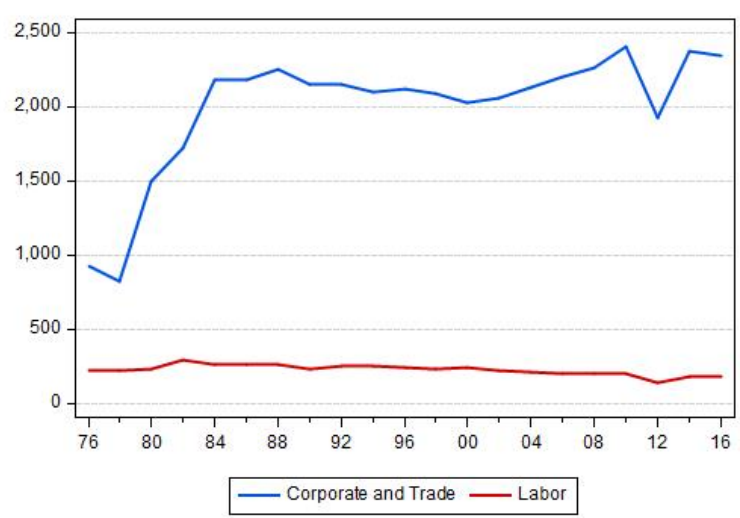

(b) Corporate and Trade, and Labor PACs, 1976-2016

Sources: (a) Vogel (1989, ch. 8); (b) The Campaign Finance Institute (2019)

At the same time, businessmen were encouraged to go to classrooms "to teach kids about business" (Phillips-Fein 2009, 203-4).

In 1971, corporations were allowed to contribute to political campaigns through political action committees (PACs). Initially, there were strict limits on how much each PAC could contribute to campaigns. Subsequently, a 1976 ruling removed any restrictions on the number of PACs each corporation was allowed to create and effectively removed any limits on the corporations' contributions to campaign financing. As figure 2 shows, this led to a very rapid increase in the number of corporate PACs. Figure 2a shows that in December 1974 there were only 89 corporate PACs; in July 1980, this number had increased to 1,204 . If we also count the trade PACs, the total for 1980 was 1,500, which increased to 2,182 in 1984 (figure 2b). At the same time, the number of labor PACs hardly increased (between 1976 and 1980 there was just one more!). In parallel, businesses developed mechanisms for better coordination of the funds of the individual PACs in order to be used where they would matter most. 
Businesses also broadened their relations with the press. Their CEOs became more personally visible, they started using consultants to improve their public image, and their expenditure on advertising increased. Business grants to the Public Broadcasting System (PBS) increased sevenfold in the years 1973 to 1979: from \$3.3 million to \$22.6 million (Vogel 1989, 216). A special form of advertising that was employed extensively was "advocacy advertising," which was used to communicate the positions of a corporation on a particular issue. For example, the Business Roundtable spent more than \$1 million for advertisements in Reader's Digest that looked like normal articles: "One piece in the 1975 series defended the very principle of profit ('Profits are not, as some people seem to think, clutched in the hands of few cigar-smoking tycoons'); another argued that 'the way we earn our daily-bread in this country is under attack like never before' and offered responses to criticisms [of the free enterprise system]" (Phillips-Fein 2009, 193).

The 1970s also saw increasing involvement of businesses in the battle of ideas. Several chairs of "free enterprise" were endowed, and many universities received funds to establish programs that would link corporations with the academic campuses, such as "executive in residence" programs. At the same time, the funding for think tanks increased rapidly and new-by now very well-known — ones appeared. The the American Enterprise Institute's budget increased from \$1 million in 1970 to $\$ 10$ million in 1980; the Heritage Foundation and the Cato Institute were founded in 1973 and 1977, respectively. The purpose of these think tanks was to produce studies and policy reports that would highlight the benefits of deregulation and the free market system. This research was a crucial contributor to the eventual dominance of these ideas and policies.

Finally, it should be noted that during the same decade, the various parts of the business community-large corporations and small businesses, corporations of different sectors, etc.-increasingly united in their efforts and objectives. At the top of their agenda was the reversal of regulation and the weakening of labor's position. 
The result was that by the late 1970s businesses had gotten the "organizational edge" (Hacker and Pierson 2010, 104), which allowed them to score some stunning legislative victories and block every labor initiative during the Carter administration. This was the prelude to the reversal of the tide. All accounts of these events point to the organization and involvement of businesses as the main reason for this reversal (Vogel 1989, 210-1; Hacker and Pierson 2010, ch. 5).

The second act included the election of Ronald Reagan as president in 1980. The election was followed in 1981 by tax cuts of unprecedented magnitude for corporations and top income brackets—-larger than anyone had ever before advocated, as Republicans and Democrats competed to appear "business friendly" — and extensive deregulation (e.g., of prices, safety and environmental standards, etc.) in 1981 and 1982. In August 1981, the administration fired 11,000 striking air-traffic controllers, which testifies to unions' rapidly decreasing influence. The economic policies of the administration, together with the economic downturn of the period (in 1982, real GDP shrank by almost 2 percent and the unemployment rate reached 10 percent), also had a significant effect on wages: in 1982 the number of work stoppages fell to its lowest level in the postwar period. In 1983, labor costs rose by 2.5 percent, as opposed to an annual rate of 8.3 percent between 1973 and 1981 (Vogel 1989, 256-7). All these factors solidified the businesses' support of the administration.

Given the economic conditions and the high unemployment rate, the midterm elections of 1982 were expected to be disastrous for the Republican Party. Conventional forecasting models were projecting a loss of around 60 seats in the House. However, the continuous support of the business community, together with the aforementioned organizational edge, allowed the Republican Party to weather this crisis. The eventual loss of 26 seats was, in comparison, small and manageable. This was the third and final act of the turn of the tide (Hacker and Pierson 2010, 165-7). 


\section{Figure 3: Political Money (amounts in \$US billion)}

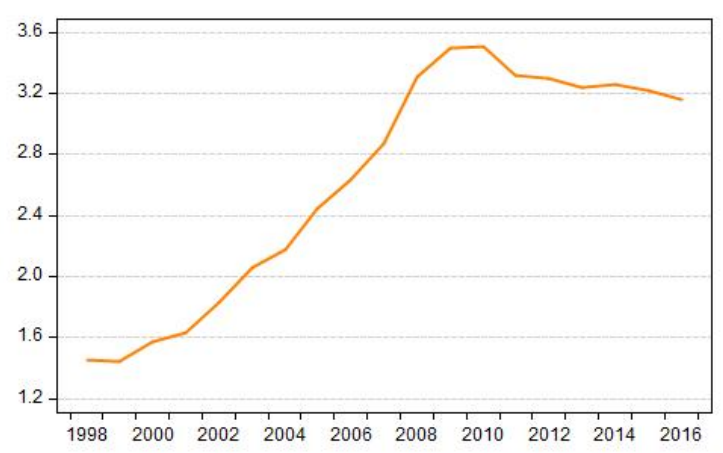

(a) Total Lobbying Spending, 1998-2016

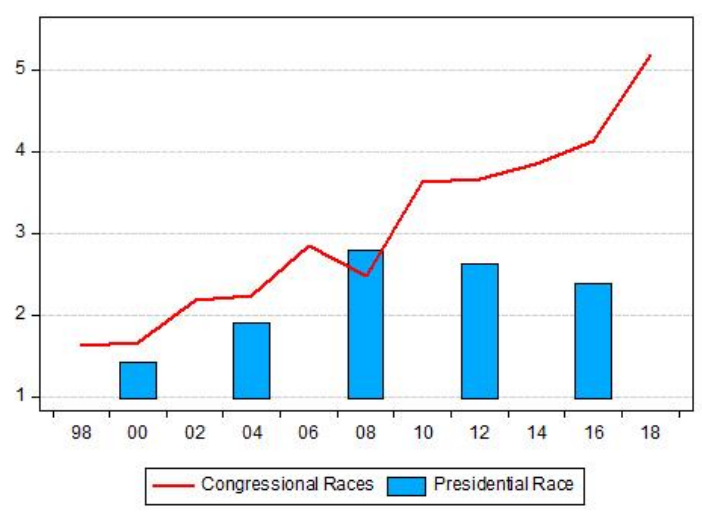

(b) Cost of Election; amounts spent on federal elections by cycle, 1998-2018

Source: Center for Responsive Politics (2019a, 2019b)

The involvement of businesses in its various forms has been increasing ever since. Large corporations bought big media organizations and the press has become much friendlier to business interests. The success of Republicans in attracting corporate money led to the Democratic Party also becoming more business friendly. For that purpose, the Democratic Leadership Council was formed in 1985. Young politicians, like Bill Clinton and Al Gore, were part of this effort, which would crystallize during the 1992 electoral campaign and the eight years of their administration. This significant shift of the whole political spectrum was then followed by a further radicalization of the Republican Party, first in the 1990s under the leadership of Newt Gingrich, and then more recently after the crisis of 2007 (Hacker and Pierson 2010).

Behind these changes one can trace large amounts of political money. In 2007, the number of lobbyists reached almost 15,000. Total lobbying spending tripled in the decade between 1998 and 2008 (figure 3a). Moreover, although the number of PACs has remained stable (figure 2b), the amount each one spends has increased. More recently the 2010 Supreme Court's "Citizens United" decision allowed the creation of the so-called super PACs, which may engage in unlimited political spending. Spending by super PACs, funded by a few megadonors, has recently become 
the most important part of campaign financing. In total, as we can see in figure $3 \mathrm{~b}$, these developments have led to an extraordinary increase in the cost of political campaigns.

Finally, it is worth mentioning that there are also many avenues of corporate influence that are totally undisclosed. For example, the term "shadow lobbying" refers to companies employing people who are clearly supposed to influence public policy but don't meet the technical definition that requires disclosure. As a result, there is no data available on it. Also, as Ferguson (2014) explains, there is a wide spectrum of de facto political money, which oftentimes goes unnoticed or is not counted as such (e.g., payments as speaking fees, book contracts, and "philanthropic advice," or funding of think tanks). In two related papers, Ferguson, Jorgensen, and Chen (2016, 2017) demonstrate the importance of political money as a driver of US elections, and provide two case studies on how the active involvement of large corporations, in various forms and especially through political spending, has secured the privileged positions of these industries in finance and telecommunications.

\subsection{Distribution}

The point of the discussion above is that distribution of income is not determined in a vacuum or in the abstract. On the contrary, the collective agency of labor and capital — their involvement—is a primary factor for its determination. As we showed, the fluctuations in income distributions have been associated with related fluctuations in involvements. Based on this we can write that:

$$
\pi=\pi_{0}+\alpha_{c} \cdot x_{c}-\alpha_{w} \cdot x_{w}
$$

where $x_{c}$ and $x_{w}$ denote the degree of involvement of the capitalist and the working class, respectively, and $\alpha_{c}, \alpha_{w}$ are positive constants; $\pi_{0}$ denotes other influences on distribution, which, for the purposes of the present paper, will be treated as an exogenous constant. Thus, equation (4) 
is simply telling us that the profit share is an increasing function of the involvement of the capitalist class and a decreasing function of the involvement of the working class. If we time differentiate equation (4) we get:

$$
\dot{\pi}=\alpha_{c} \cdot \dot{x}_{c}-\alpha_{w} \cdot \dot{x}_{w}
$$

where the dot stands for the time derivative.

\section{INDUCED SHIFTING INVOLVEMENTS}

The discussion above implies that in order to arrive at a theory of distribution, we need to specify how the involvement of each class is determined. Starting from the capitalists, it is assumed that they have a target level of distribution $\left(\pi_{c}^{t}\right)$ and they shift their level of involvement in response to discrepancies between the target and the actual level of the profit share.

Moreover, an important factor that affects the degree of involvement in something - that Hirschman neglected in his own discussion-is the cost of involvement: engagement and organization have a cost in terms of effort required, strategic implementation, and also material resources. We will thus assume that the change in involvement will be negatively affected by the marginal cost of this increase in their level of involvement $\left(M C_{c}\right)$. These two factors can be summarized in the following equation:

$$
\dot{x}_{c}=\rho_{0 c}+\rho_{1 c}\left(\pi_{c}^{t}-\pi\right)-\rho_{2 c} M C_{c}
$$

where $\rho_{1 c}$ and $\rho_{2 c}$ are positive constants, and $\rho_{0 c}$ captures other possible influences on the trajectory of capitalist involvement, which will be treated as exogenous. 
The next question then is how do capitalists determine their target level of the profit share. It will be assumed that this target level of the profit share is a positive function of the current profit share and a negative function of the degree of wage-ledness $(\lambda)$. This can be written this as:

$$
\pi_{c}^{t}=\beta_{1 c} \cdot \pi-\beta_{2 c} \cdot \lambda
$$

where $\beta_{1 c}$ and $\beta_{2 c}$ are positive constants.

There are several reasons why the target profit share will be higher the higher the current profit share is. Profit share is a basic part of the two main motives of capitalists: i) the power motive; and ii) the economic motive. The power motive refers to the wish of capitalists to control the production and political processes, even if that comes at the cost of a lower level of economic activity, and thus profitability. Kalecki (1943) in his "Political Aspects of Full Employment," famously noted that "industrial leaders" often dislike government policies that maintain full employment because these policies are associated with loss of control over production, allocation of resources, and the political and social process. Based on this category of motives, capitalists will target the highest profit share possible.

On the other hand, the economic motive is related to the profit rate. The profit rate is equal to the product of the profit share and capacity utilization: $r=\pi \cdot u$. Hence, the profit share is also part of the economic motivation. At any level of utilization, a higher profit share will also increase the profit rate. Therefore, we can expect that, ceteris paribus, capitalists would target the highest profit share possible.

At the same time though, their aspirations regarding the profit share are conditioned by the current profit share; in every period the current distribution acts as a "constraint" to these aspirations. As a 
result, as the profit share increases, capitalists target an even higher share of income. In terms of equation (7), that means that $\beta_{1 c}>1$.

However, because capacity utilization is part of the profit rate, when it comes to the economic motive capitalists are also interested in the macroeconomic performance of the economy, and therefore in the potential effects changes in distribution could have on it. As a result, the degree of wage-ledness of the economy $(\lambda)$ plays a role. The more wage led the economy is-the more positive $\lambda$ is - the more severe the fall in utilization following an increase in the profit share will be. On the other hand, in a profit-led economy, an increase in the profit share will increase utilization and this will further increase the profit rate. These considerations will obviously have weight in the firm's decisions and their target profit share. Hence, $\lambda$ will have a negative effect on $\pi_{c}^{t}$

Capitalists' interest in the macro performance of the economy can also be associated with other historical or institutional factors. For example, it is generally accepted that the fear of an increase in the influence of the Soviet Union, as well as the experience of the Great Depression and the two world wars, induced the capitalist classes in the United States and Europe to prioritize full employment in the decades after the war. Related to that, the relative magnitude of $\beta_{1 c}$ and $\beta_{2 c}$ will also depend on the specific "variety of capitalism" (Soskice and Hall 2001). For example, the social arrangements of Scandinavian capitalism are different from those in the United States and would favor a relatively strong $\beta_{2 c}$. Finally, the relative magnitude of $\beta_{1 c}$ and $\beta_{2 c}$ will also depend on the balance of power within the capitalist class. If industries with income-inelastic demand dominate, we should expect that $\beta_{1 c}$ would be relatively lower than $\beta_{2 c}$ and vice versa.

To close the discussion of capitalist involvement, we need to specify the cost component. As mentioned above, this cost can be related to the amount effort required, strategic implementation, and also material resources. For the purposes of this model it is assumed that there are increasing 
returns to involvement, so that the marginal cost is a negative function of the profit share:

$$
M C_{c}=-m_{c} \cdot \pi
$$

where $m_{c}>0$. The idea here is that as a class becomes stronger and its share of income increases, further advancement of its position become easier. There are several reasons for this. First, imagine that someone wants to get involved. If the general level of involvement is low, then it is likely that they will not know how to get involved. A higher general level of involvement provides an "infrastructure" for those who want to get involved. In the case of the capitalists, in the equation above, a higher profit share signifies a higher general level of involvement. Second, a higher profit share also provides a higher amount of material resources that can be used for the further advancement of general involvement, which also contributes to the increasing returns to involvement. A third contributing factor is that a higher profit share shows that involvement can be effective, and therefore encourages further involvement. Finally, a higher level of involvement is likely to lead to institutional changes that make further increases in involvement easier.

Thus, combining equations (6), (7), and (8), we end up with the following equation for the change in the involvement of the capitalists:

$$
\dot{x}_{c}=\rho_{0 c}+\left[\rho_{1 c} \cdot\left(\beta_{1 c}-1\right)+\rho_{2 c} \cdot m_{c}\right] \pi-\rho_{1 c} \cdot \beta_{2 c} \cdot \lambda
$$

We can specify the involvement of workers in a symmetrical way; however, symmetrical does not mean identical, since the magnitude of the various effects can be widely different. As before, and for analogous reasons, the change in workers' involvement will respond to the discrepancy between the targeted level of their income share and the actual one, and will be negatively affected 
by the marginal cost of this involvement $\left(M C_{w}\right)$. This can be written as:

$$
\dot{x}_{w}=\rho_{0 w}-\rho_{1 w}\left(\pi_{w}^{t}-\pi\right)-\rho_{2 w} M C_{w}
$$

where $\rho_{1 w}$ and $\rho_{2 w}$ are positive constants and $\rho_{0 w}$ captures other possible influences on the trajectory of capitalist involvement, which is treated as exogenous. ${ }^{4}$

The targeted share of income of the working class is a positive function of the wage share and a positive function of wage-ledness. Expressed in profit share, it can be written as:

$$
\pi_{w}^{t}=\beta_{1 w} \cdot \pi-\beta_{2 w} \cdot \lambda
$$

where $\beta_{1 w}>1$ and $\beta_{2 w}>0$. As in the case of capitalists, this behavior is based on the power and economic motives of the workers (albeit one could argue that the power motive is relatively weaker in this case). Also, as before, the current configuration of distribution acts as a constraint for the ambitions of the working class. Moreover, the relative magnitude of $\beta_{1 w}$ and $\beta_{2 w}$ is associated with historical and institutional factors, like the specific "variety of capitalism." Again, the social arrangements of Scandinavian capitalism would favor a relatively strong $\beta_{2 w}$ as opposed to the American variety, where $\beta_{1 w}$ would be relatively stronger. Finally, the relative magnitude of $\beta_{1 w}$ and $\beta_{2 w}$ depends on the balance of power among workers. If "insiders" who are not very much interested in the overall employment level but prioritize real wage increases dominate, then $\beta_{1 w}$ will tend to be relatively higher and vice versa.

\footnotetext{
${ }^{4}$ Note that workers will increase their involvement if the target wage share is higher than the actual one $\left(\psi_{w}^{t}>\psi\right)$; expressed in profit shares, as in equation (10), that means that they will decrease their involvement when the targeted profit share is higher than the actual one.
} 
Finally, for similar reasons, the marginal cost will be a negative function of their share of income, and therefore a positive function of the profit share:

$$
M C_{w}=m_{w} \cdot \pi
$$

Combining equations (10), (11), and (12), we end up with:

$$
\dot{x}_{w}=\rho_{0 w}-\left[\rho_{1 w} \cdot\left(\beta_{1 w}-1\right)+\rho_{2 w} \cdot m_{w}\right] \pi-\rho_{1 w} \cdot \beta_{2 w} \cdot \lambda
$$

The equations for the change in the involvements of the capitalist and the working class allow us to define the change in the profit share. Plugging equations (9) and (13) into equation (5), we get:

$$
\begin{aligned}
& \dot{\pi}=\left\{\alpha_{c} \rho_{0 c}-\right.\left.\alpha_{w} \rho_{0 w}\right\}+ \\
&\left\{\left[\alpha_{c} \rho_{1 c}\left(\beta_{1 c}-1\right)+\alpha_{w} \rho_{1 w}\left(\beta_{1 w}-1\right)\right]+\left[\alpha_{c} \rho_{2 c} m_{c}+\alpha_{w} \rho_{2 w} m_{w}\right]\right\} \cdot \pi \\
&-\left\{\alpha_{c} \rho_{1 c} \beta_{2 c}+\alpha_{w} \rho_{1 w} \beta_{2 w}\right\} \cdot \lambda
\end{aligned}
$$

which can be rewritten as:

$$
\dot{\pi}=\delta_{0}+\delta_{1} \pi-\delta_{2} \lambda
$$

where $\delta_{0}, \delta_{1}$, and $\delta_{2}$ are equal to the three curly brackets of equation (14), respectively. The sign of $\delta_{0}$ is not certain a priori, while $\delta_{1}$ and $\delta_{2}$ are positive (since all the parameters are positive and $\left.\beta_{1 c}, \beta_{2 c}>1\right)$.

To sum up, distribution is unstable, since $\delta_{1}>0$. There are two sources of this instability: the positive effect that each class's share of income has on its targeted share of income, and the increasing returns to involvement. On the other hand, the change in the profit share is a negative function of the wage-ledness of the economy $(\lambda)$. 
The two elements of the behavior of the profit share capture two important features of the political economy of the distribution of income, as was discussed above. To begin with, distribution tends to be unstable. In the introduction, the increase in income inequality in the last four decades was mentioned as an example. In another example, greater participation on behalf of the workers was a crucial contributing factor in the adoption of New Deal policies and the redistribution of income in their favor. At the same time, New Deal policies, like the Wagner Act of 1935, were instrumental in making workers' involvement and organization easier by preventing employers from interfering with workers' unions and protests in the private sector. The Act also established the National Labor Relations Board (NLRB) to protect workers' rights to organize, bargain collectively, and strike. These institutional changes allowed further increases in union participation and a further increase in workers' share of income.

On the other hand, the negative effect of wage-ledness is a factor that can potentially contain this instability. In a wage-led (profit-led) economy, a continuous increase in the profit (wage) share leads to crisis and stagnation. It is exactly this crisis that can break the instability and catalyze the change in the direction of the distribution of income. It is not accidental that the two major changes in the direction of income distribution during the 20th century were preceded by a crisis. As Hacker and Pierson (2010, 87-90) write, a crisis is a necessary condition for the "politics of renewal" because it acts as a catalyst for the necessary changes. The crisis of the last decade has also catalyzed significant changes in the political economy of the United States; it remains to be seen if these changes will be enough to turn the tide or if instability will prevail. 


\section{CHANGES IN DISTRIBUTION-LEDNESS}

The distinction between wage- and profit-led growth emanates from the dual nature of wages. Wages are the income of the majority of the population (whose consumption rate is also high), and, at the same time, the major cost for firms. It is exactly because of this duality that one of these natures cannot completely dominate the other. If an economy is at a certain period of time and level of distribution, say, profit led, it would be absurd to suggest that this means that the highest growth rate would be achieved at a profit share of 100 percent. Similarly, even if an economy is wage led, we would not expect it to grow at its highest rate when the profit rate is zero. It is reasonable to expect that wage-ledness is endogenous to the level of distribution. ${ }^{5}$ More precisely, we would expect an economy to become more wage led as the profit share increases and vice versa. In this section, an explanation of why this might happen is provided.

One of the most interesting stylized facts of the last 30 years is that - as the profit share has increased - there has been a gradual decoupling of the corporate cash flows generated by profits (and borrowing) from investment. Instead, these cash flows have increasingly been used for share buybacks and dividend payments. ${ }^{6}$ For example, the main justification for the recent corporate tax cuts was that they would boost investment. The first evidence shows that the increase in cash flows has instead led to an explosion of share buybacks. A survey by the National Association for Business Economics for the third quarter of 2018 found that the tax cuts had little or no effect on firms' investment plans (NABE 2018). Similarly, Smolyansky, Suarez, and Tabova (2018) show that the majority of the repatriated funds were used on share buybacks. ${ }^{7}$

\footnotetext{
5 The endogenous character of the distribution-led regimes has been recently emphasized in Nikiforos (2016b) and Marglin (2017).

6 Mason (2015) provides some empirical evidence using aggregate and firm-level data.

7 There are several articles in the financial press that report similar results. For example, an October 29 article in the Financial Times has the explicit title "US tax cut said to have little impact on investment: Survey adds to the evidence that much of the windfall was used for share buybacks" (Edgecliffe-Johnson and Crooks 2018).
} 
There are several explanations for this behavior of the propensity to invest out of the profit share. To begin with, current profitability is important for investment as a proxy for future profitability; an increase in current profitability creates the expectation that future profitability will be high or increase as well. It is possible that the linkage between current and expected profitability weakens, at least after a certain point, and other factors become more important for the formation of expectations. Importantly, if an economy has entered a wage-led phase, firms realize that an increase in their share of income will not lead to higher demand. Stagnating demand plays an increasingly important role in the investment decisions of the firm. Related to that, as Baran and Sweezy (1966) explain, an increase in the profit share is often associated with an increasing monopolization of the markets by some giant corporations. The surplus these firms can extract (increasingly) exceeds the accumulation requirements.

Another role of profitability is that it provides internal funds, which are safer than borrowed funds for financing the investment plans of a firm. The classic treatments here include chapter 11 of The General Theory (Keynes 2013 [1936]), "the principle of increasing risk" (Kalecki 1937), and the related discussion by Minsky (1986, ch. 8). It is also possible that internal funds constraints become less binding as these internal cash flows increase (due to the increase in the share of profit). This could be part of the explanation of why so many US corporations hoard huge piles of cash. ${ }^{8}$ The recent unresponsiveness of investment to the corporate and repatriation tax rates is also a testament to the relaxation of this constraint. ${ }^{9}$

Finally, and related to the above, periods of increasing profitability are usually associated with increasing power of the financial sector. Polanyi (2001 [1944]) referred to the haute finance of the

\footnotetext{
8 According to market analysts' latest estimates, as of 2017, US corporations had accumulated between $\$ 1.5$ trillion and \$2.5 trillion in cash. In an earlier study, Sánchez and Yurdagul (2013) estimate that the "Aggregate Cash and Equivalents of Non-Financial Non-Utility Firms" increased from \$100 billion in 1980 to \$1.6 trillion in 2011.

9 Similar conclusions have been reached about the 2004 Homeland Investment Act, which gave a repatriation tax holiday for US corporations. For example, Dharmapala, Foley, and Forbes (2011) find that for every \$1 repatriated there was an increase of $\$ 0.79$ in share repurchases and $\$ 0.15$ increase in dividends.
} 
late 19th and the first decades of the 20th century. In current times, the last four decades have been characterized as the period of financialization. In a finance-dominated environment, it is becoming more and more appealing to firms to "invest" their retained cash flows in the financial markets instead of using them for fixed capital investment. As was already mentioned, over the last four decades, an increasingly large share of firms' retained profits and borrowing has been used for share buybacks or the purchase of equities issued by other firms. ${ }^{10}$

Based on the above, it can be assumed that the time derivative of $g_{\pi}^{i}$ is a function of the deviation of the profit share from its long-run value $\left(\pi-\pi^{*}\right)$, with a negative partial derivative. It can also be assumed that the time derivative of $g_{\pi}^{i}$ is a function of $g_{\pi}^{i}$ itself, with its partial derivative being negative. That is, as $g_{\pi}^{i}$ increases, a further increase of $g_{\pi}^{i}$ becomes more and more difficult. Overall, one can write:

$$
\dot{g}_{\pi}^{i}=f\left(g_{\pi}^{i}, \pi-\pi^{*}\right)
$$

where $\partial \dot{g}_{\pi}^{i} / \partial g_{p i}^{i}<0$ and $\partial \dot{g}_{\pi}^{i} / \partial \pi<0$. The resulting $\dot{g}_{\pi}^{i}=0$ nullcline has a negative slope.

Another important development in the last four decades is that as income has concentrated toward the households at the top of the distribution, their savings rate increased as well. For example, data from the Bureau of Labor Statistics' Consumer Expenditure Survey show that the savings rate of the top 20 percent of American households increased by 11 points as a percentage of their income after taxes between 1989 and 2010 (the same figure is 18 points as a percentage of income before taxes). ${ }^{11}$

\footnotetext{
${ }^{10}$ For a discussion of financialization, see Boyer (2000), Lazonick and O'Sullivan (2000), Stockhammer (2004), Epstein (2005), Orhangazi (2008), and Lazonick (2014, 2015).

${ }^{11}$ I should note, however, that the savings rate is sensitive to what one defines as expenditure and disposable income (Cynamon and Fazzari 2015). Hence, there are studies with different results.
} 
To a certain extent, this increase is related to the standard stylized fact that the savings rate of rich households is higher than the savings rate of poor households. ${ }^{12}$ If increases in income cross-sectionally are associated with increasing savings rates, we could expect that the increase in the income of a certain household can lead to an increase in its savings rate. This is especially plausible for households at the top of income distribution that do not have other households above them to emulate. ${ }^{13}$

There are also other theoretical reasons for that. First, in line with Ramsey (1928), one can explain this kind of behavior of saving by the existence of a bliss point. As the consumption of rich households approaches this point, further increases in their income lead to increases in their savings rate. Also, in chapter 9 of The General Theory, Keynes provides "eight main motives or objects of a subjective character which lead individuals to refrain from spending out of their incomes." Out of these motives one could explain an increase in the savings rate as the income increases with: i) the motive to build-up reserves against unforeseen contingencies, ii) the motive to bequeath a fortune, and, finally, iii) the satisfaction of "pure miserliness, i.e., unreasonable but insistent inhibitions against acts of expenditure as such" (Keynes 2013 [1936], 107-8).

Based on the above, we will assume the following specification for the propensity to save out of the profit share:

$$
\dot{g}_{\pi}^{s}=h\left(g_{\pi}^{s}, \pi-\pi^{*}\right)
$$

where $\partial \dot{g}_{\pi}^{s} / \partial \pi>0$. Moreover, it will also be assumed that $\partial \dot{g}_{\pi}^{s} / \partial g_{p i}^{s}<0$. That is, as the propensity to save out of the profit share increases, a further increase becomes harder. The resulting $\dot{g}_{\pi}^{S}=0$ nullcline has a positive slope.

\footnotetext{
12 This is an empirical observation - shared, among others, by classical political economists, Keynes in chapter 10 of The General Theory (Keynes 2013 [1936]), and Samuelson (1939, 793-95) — that underlies the assumption that the propensity to save out of the profit share is positive.

${ }^{13}$ For a review of the literature on emulation as a factor of household consumption behavior, see Nikiforos (2016a, 585-88).
} 
Overall, using equations (15) and (16) and the definition of wage-ledness $(\lambda)$, we can write:

$$
\dot{\lambda}=z\left(\lambda, \pi-\pi^{*}\right)
$$

with $\partial \dot{\lambda} / \partial \lambda<0$ and $\partial \dot{\lambda} / \partial \pi>0$. For reasons of simplicity, we can define a linear specification for $z(\cdot)$ :

$$
\dot{\lambda}=\eta_{1}\left(\pi-\pi^{*}\right)-\eta_{2} \lambda
$$

where $\eta_{1}$ and $\eta_{2}$ are positive constants.

\section{INSTABILITY AND CYCLES}

The system described in the two previous sections can be summarized with equations (14) and (18), which form a two-dimensional dynamic system:

$$
\left[\begin{array}{c}
\dot{\pi} \\
\dot{\lambda}
\end{array}\right]=\left[\begin{array}{c}
\delta_{0} \\
-\eta_{1} \cdot \pi^{*}
\end{array}\right]+\left[\begin{array}{cc}
\delta_{1} & -\delta_{2} \\
\eta_{1} & -\eta_{2}
\end{array}\right] \cdot\left[\begin{array}{l}
\pi \\
\lambda
\end{array}\right]
$$

It is not hard to see that the steady state is $\left(\pi^{*}, \lambda^{*}\right)=\left(\pi_{0}-\delta_{0} / \delta_{1}, 0\right) .{ }^{14}$

The dynamics of the system are interesting and can be discussed with reference to the Jacobian matrix of the system - the $2 \times 2$ matrix on the right-hand side of equation (19). For stability, two conditions are necessary: i) the trace $(\tau)$ of the Jacobian has to be negative, and ii) its determinant (D) has to be positive.

Starting from the first one, for the trace to be negative $\left(\tau=\delta_{1}-\eta_{2}<0\right)$ the unstable tendency of distribution $\left(\delta_{1}\right)$ has to be relatively weak compared to the tendency of $\lambda$ to stabilize $\left(\eta_{2}\right)$. As

${ }_{14}$ Obviously, for the solution to make economic sense, $\pi^{*}=\pi_{0}-\delta_{0} / \delta_{1}$ has to be positive. 
explained above, there are two main forces that make distribution unstable: the positive effect that each class's share of income has on its targeted share of income and the increasing returns to involvement. Stability requires that these forces are relatively weak.

Second, for the determinant of the Jacobian to be positive $\left(D=\eta_{1} \delta_{2}-\delta_{1} \eta_{2}>0\right)$, the negative feedback effect of $\lambda$ on the change in the profit share $\left(\delta_{2}\right)$ and the positive feedback effect of an increasing profit share on the change in the degree of the wage-ledness $\left(\eta_{1}\right)$ need to be strong. In other words, stability requires that the two classes are interested in the macroeconomic performance of the economy and, as a result, distribution-ledness strongly affects the intensity of their involvement. Also, as the profit share increases, the degree of distribution-ledness of the economy changes fast. The second condition can be rewritten as $\eta_{1} / \eta_{2}>\delta_{1} / \delta_{2}$. Therefore from a geometric point of view, stability requires that the slope of the $\dot{\lambda}=0$ nullcline is higher than the slope of the $\dot{\pi}=0$ nullcline. ${ }^{15}$

\subsection{Instability}

Both the unstable and the stable configuration of the model are interesting. Starting from the unstable configuration, the model is telling us that if the two classes in a capitalist system are interested solely in increasing their power position and the share of their income, while disregarding the macroeconomic performance of the economy, the system becomes unstable. Other factors, outside of the scope of the present model, then come to stabilize it. In historical perspective, the long crisis in Europe in the period between WWI and the end of WWII can be partly understood through this lens: a crisis that was caused by the push of the capitalist class to increase their share of income, which was eventually resolved through wars and the emergence of Nazism.

15 The $\dot{\pi}=0$ nullcline can be written as $\lambda=\delta_{0} / \delta_{2}+\left(\delta_{1} / \delta_{2}\right) \pi$, and the $\dot{\lambda}=0$ nullcline can be written as $\lambda=\left(\eta_{1} \delta_{0}\right) /\left(\eta_{2} \delta_{1}\right)+\left(\eta_{1} / \eta_{2}\right) \pi$. In both cases the intercept is negative because $\delta_{0}<0$ and the slope of the nullclines is positive in the $(\pi, \lambda)$ space. 


\section{Figure 4: Unstable Configuration}

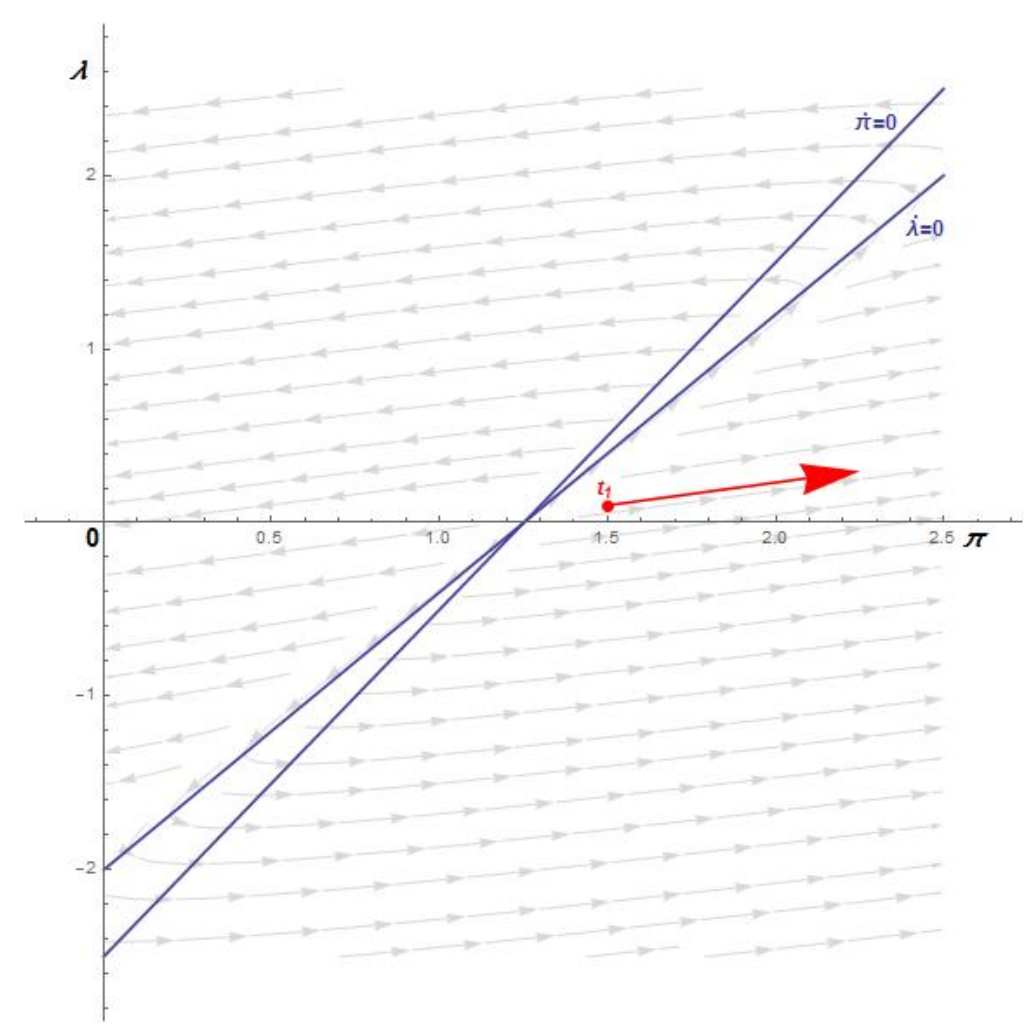

An unstable configuration of the model is presented in figure 4. In period $t_{1}$, the economy is wage led, since $\lambda>0$. However, the profit share is increasing. The increase in the profit share obviously leads to lower utilization-since the economy is wage led-but over time also makes the economy more wage led and thus successive increases in the profit share cause increasingly large drops in utilization. Because distribution is highly unstable (high $\delta_{2}$ ), the economy drifts away from the steady state, along the red line. ${ }^{16}$

\footnotetext{
16 The case presented in figure 4 is one of an unstable node. Depending on the magnitude of the parameters, we could have other types of instability. If the slope of the $\dot{\lambda}=0$ nullcline was lower than the slope of the $\dot{\pi}=0$ nullcline, we would have saddle-path instability. On the other hand, higher values of the off-diagonal elements of the Jacobian would create an unstable spiral.
} 


\subsection{A Polanyian Predator-Prey Cycle}

If the configuration of the model satisfies the conditions for stability and since we have one stable and one unstable nullcline, chances are that we will have cyclical convergence. Such a configuration is presented in figure 5. Starting again from period $t_{1}$, the economy is wage led and the profit share increases (since we are below the $\dot{\pi}=0$ nullcline), which makes the economy more wage led. As before, the combination of an increasingly positive $\lambda$ and an increasing profit share lead to a crisis: lower utilization levels with increasing speed. However, unlike the previous case, the restoring forces of the system are strong enough to pull the trajectory above the $\dot{\pi}=0$ nullcline at period $t_{2}$. After that, the profit share decreases. The decrease in the profit share, together with the economy being wage led, lead to an upswing. In fact, at this stage of the cycle, $\lambda$ increases as well, so the decreases in $\pi$ lead to increases in $u$ with accelerating speed.

However, at period $t_{3}$, the trajectory crosses the $\dot{\lambda}=0$ nullcline; after that, as $\pi$ decreases, the economy tends to become less wage led. Eventually the economy becomes profit led at period $t_{4}$. The wage share keeps increasing and the economy becomes more profit led, so we have an accelerating decline in utilization and a crisis. The solution to the crisis is given with the change in the direction of distribution. At period $t_{5}$, the trajectory again crosses the $\dot{\pi}=0$ nullcline but in the opposite direction. The economy starts growing fast since both $\pi$ increases and $\lambda$ decreases. However, after period $t_{6}$, the increase in $\pi$ will eventually lead to an increase in $\lambda$. Finally, after period $t_{7}$, we have made a full circle and returned to a crisis situation with an increasing profit share and an increasingly positive $\lambda$.

The cycles in figure 5 echo some insights from Karl Polanyi’s Great Transformation (2001 [1944]) and his concept of the double movement. Polanyi argues that as capitalism became the main mode of production in Western societies, there was a push to disembed the market sphere from the wider social and political sphere. However, eventually this led to a crisis, which in turn 
Figure 5: Polanyian Predator-Prey Cycles (wage-ledness $[\lambda]$ is the predator and distribution $[\pi]$ is the prey)

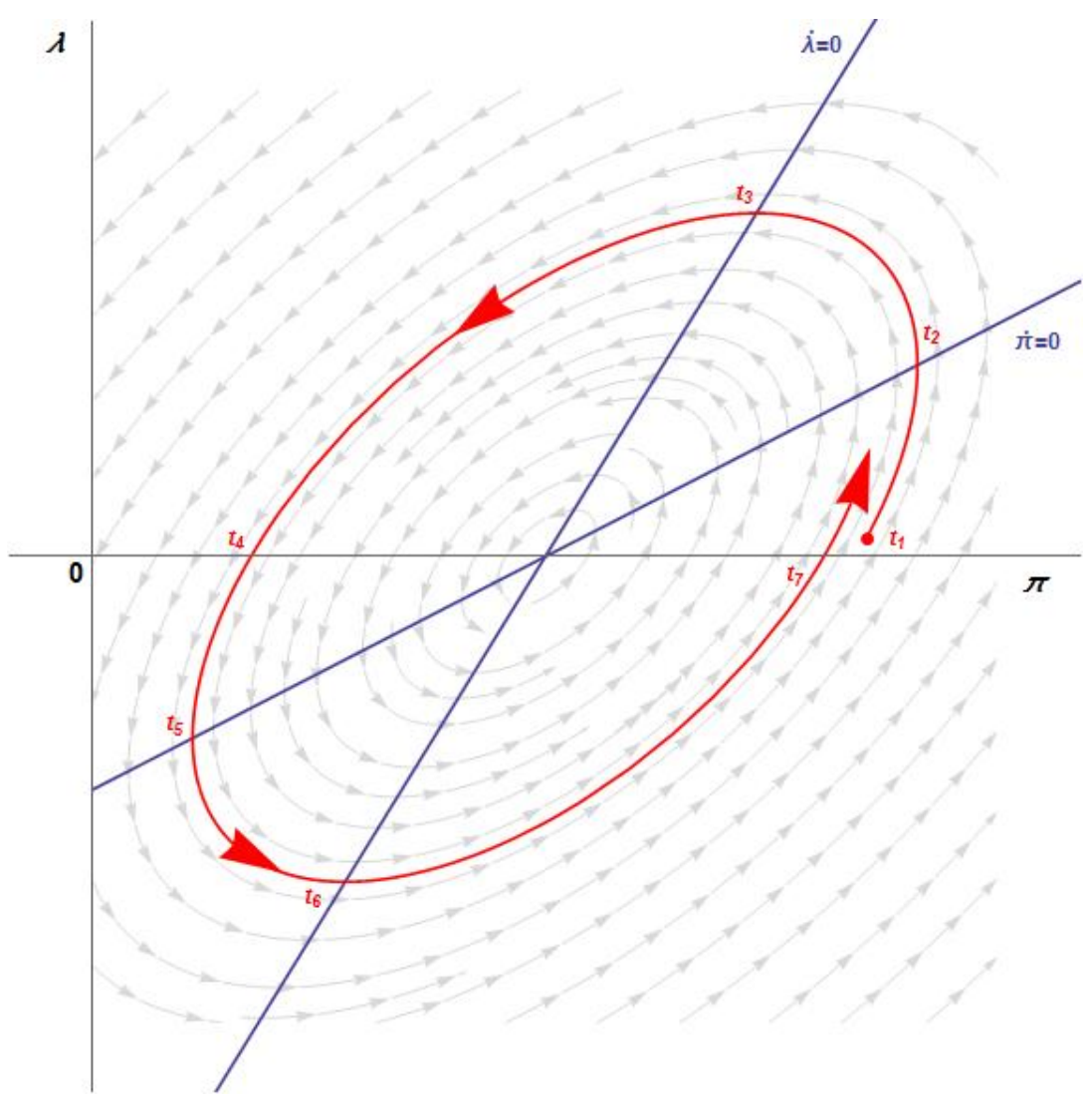

caused a spontaneous reaction against the laissez-faire arrangements and tried to reembed the economic sphere into the more general social arrangements. ${ }^{17}$ Polanyi, writing his book in 1944, described only one swing of pendulum: the push for the laissez-faire and the push back. However, it would be straightforward to interpret the rise of neoliberalism within the same framework: the countermovement also led to a crisis, which then caused a reaction in the opposite direction and swung the pendulum back toward laissez-faire. ${ }^{18}$

17 The crisis in The Great Transformation is not only economic, like in our model; it is also related to the destruction of social institutions, as well environmental degradation. Another important difference is that Polanyi's argument is not stated in class terms - both labor and capital participate in the reaction.

${ }^{18}$ Helleiner (1996), Silver and Arrighi (2003), and Maertens (2008) discuss neoliberalism based on the double movement. 
The model presented here can be understood along these lines. The Polanyian element is the inclusion of wage-ledness $(\lambda)$ as a factor that affects the involvements. When the profit or the wage share increase too much, a crisis ensues. The crisis causes a reaction in the form of shifting involvements, which in turn change the direction of income distribution and resolve the crisis.

The counterclockwise cycles of figure 5 also resemble a predator-prey model (Lotka 1910; Volterra 1931), where distribution is the prey and wage-ledness is the predator. As is well-known, it was Richard Goodwin (1967) who first modeled the symbiosis of the two classes_partly complementary, partly hostile-based on the predator-prey equations, with the growth rate being the prey and distribution the predator. Empirical observation shows that the Goodwin model provides a good way to think about the business cycle, at least during certain historical periods.

This paper's model reverses the role of distribution, which now becomes the prey. If it was not for the restoring forces of the system, the profit share (or the wage share) would tend to continuously increase. The increase in the profit share leads to an increase in the level of $\lambda$, the predator of our system. The crisis that ensues will catalyze a change in the intensity of the involvement of the two classes and eventually a switch in the direction of the distribution of income. The decreases in the level of the prey $(\pi)$ will eventually lead to a decrease in the level of the predator $(\lambda)$, another crisis, and will in turn catalyze a shift in the involvements in the opposite direction and eventually the direction of the distribution of income will switch back.

This is another way to think about the partly complementary/partly hostile symbiosis of workers and capitalists within the capitalist system. Compared to the Goodwin model, it is more appropriate for long-run variations in distribution and growth. The present-Polanyian predator-prey-model is helpful for understanding the dynamics of the US economy during the 20th century. The increase in inequality and the profit share in the early decades of the century led to the crisis of the 1930s. The crisis led to the New Deal and the institutions that dominated the 
early postwar period. As Marglin and Bhaduri (1990) argue, the US economy was wage led at that period, but then became increasingly profit led as we approached the 1970s. As a result, the institutions that provided the solution to the crisis of the 1930s endogenously led to the crisis of the 1970s, which was a profitability crisis that induced stronger involvement of capitalists and lower involvement of workers. This is another way to explain the shifting involvements Hirschman was observing at that time. The change in involvements led to the establishment of the neoliberal order of the 1980s. Since then, the increase in the profit share made the American economy more and more wage led and eventually led to the recent crisis and ongoing stagnation.

Phenomena like the emergence of the Occupy Wall Street movement, and the popularity of self-proclaimed socialist politicians and of Piketty's Capital in the 21st Century (2014) are all signs of a spontaneous reaction and the shifting involvements of our time. It remains to be seen if, how, and when the $\dot{\pi}=0$ nullcline will be crossed.

\section{COOPERATION AND CONFLICT}

Bhaduri and Marglin (1990) provide an interesting extension to the dichotomy between wage- and profit-led growth, arguing that each one of these regimes can be further distinguished into cooperative and conflictual subregimes. This further dichotomy forms the "economic basis for contesting political ideologies," as the title of their paper goes. The basic idea is that if an economy is strongly wage led, a decrease in the profit share will lead to a large increase in utilization and an increase in the profit rate, thus making both classes better off. This is the cooperative wage-led case. If utilization does not respond strongly, then we are in a conflictual wage-led case, since the decrease in the profit share will lead to a decrease in the profit rate as well. 
Similarly, in the profit-led case, if utilization responds strongly to a decrease in the wage share, a redistribution of income toward profits might increase the wage bill, normalized to potential output (an equivalent to the profit rate of the working class). This is the cooperative profit-led regime. Under the conflictual profit-led regime, the wage bill, normalized for potential output, decreases as the profit share decreases.

The cooperative wage-led regime provides the economic justification for traditional "left-Keynesian" social-democratic policies: a redistribution of income toward wages will eventually benefit both workers and capitalists. On the opposite end, the cooperative profit-led case is the usual justification for "trickle-down" policies. The redistribution of income toward profits will boost aggregate activity and, thus, eventually benefit everyone.

More formally, the condition for a cooperative wage-led economy is that a decrease in the profit share will increase the profit rate, $d(\pi u) / d \pi<0$, which can be rewritten as:

$$
\frac{d(\pi u)}{d \pi}<0 \Leftrightarrow \lambda \cdot \frac{\pi}{u}>1
$$

This is an elasticity condition, which will tend to be satisfied when $\lambda$ and $\pi$ are high, and when $u$ is low. With reference to the cycle of $\lambda$ and $\pi$ in figure 5 , this condition will tend to be satisfied around the time period $t_{2}-t_{3}$. In the remaining wage-led phase of the cycle, the economy will be conflictual.

Similarly, the condition for a cooperative profit-led economy is that an increase in the profit share will increase the wage bill, normalized for potential output, $d[(1-\pi) u] / d \pi>0$, which can be rewritten as:

$$
\frac{d[(1-\pi) u]}{d \pi}>0 \Leftrightarrow-\lambda \cdot \frac{\pi}{u}>\frac{\pi}{1-\pi}
$$




\section{Figure 6: Cycles of Conflict and Cooperation}

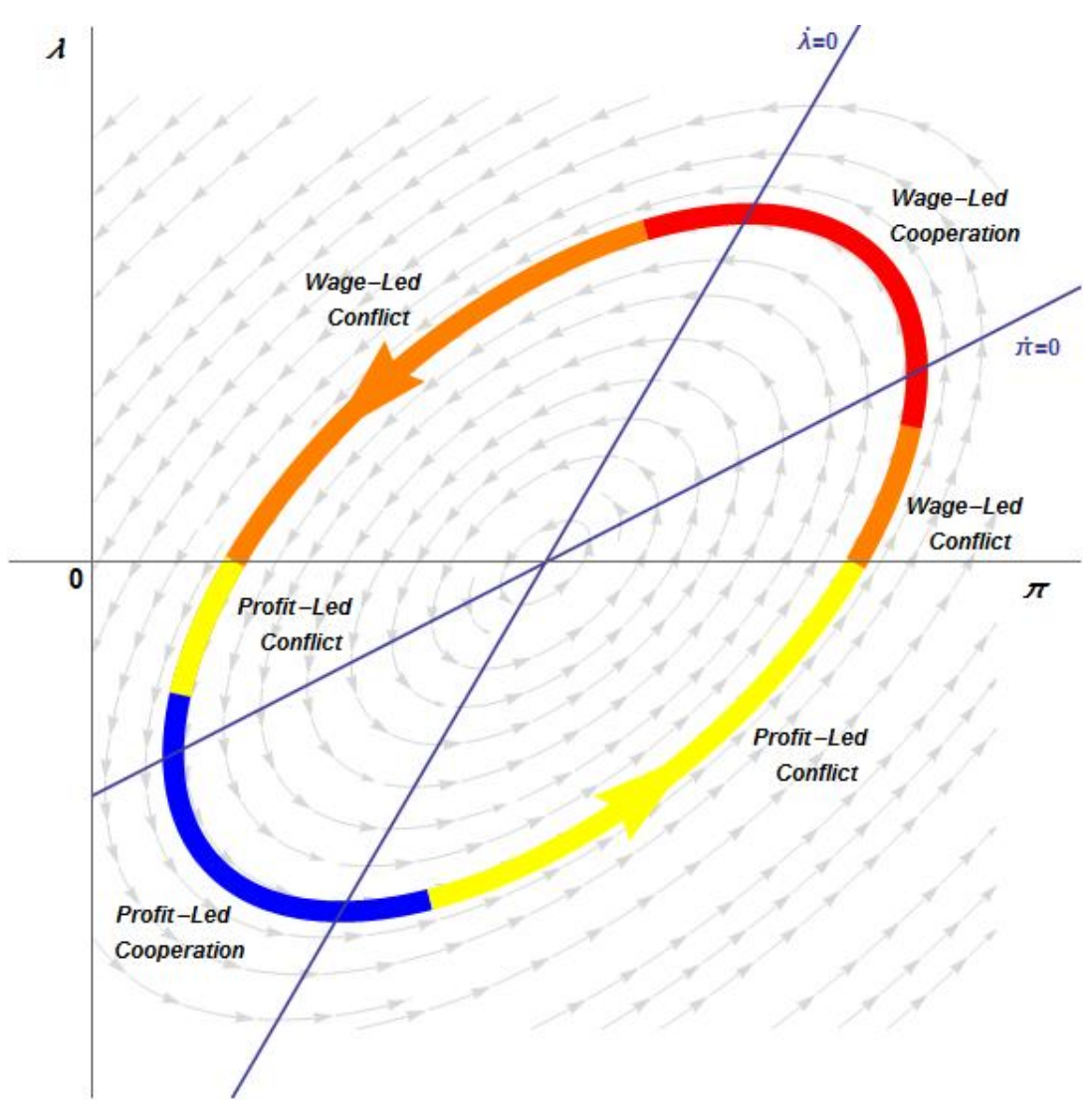

This condition will be satisfied when $\lambda, \pi$, and $u$ are low. With reference to the cycle in figure 5, this condition will tend to be satisfied in the period around $t_{5}-t_{6}$. In the remaining profit-led phase of the cycle, the economy will be conflictual.

These results are summarized in figure 6. As we can see, based on the cyclical configuration of the aforementioned model, the economy will move from being conflictual wage led (the orange segment of the line) to cooperative wage led (the red segment), back to conflictual wage led, and then conflictual profit led (the yellow segment), cooperative profit led (the blue segment), conflictual profit led, and eventually back to conflictual wage led. The exact time periods where the switch between the regimes will take place depends on the specification of the model. 
More generally, we can assume that capitalists are interested in a weighted average of the profit share and utilization, $\pi^{a_{c}} u^{b_{c}}$. The profit rate is a special case of that, with $a_{c}=b_{c}=1$. Under this assumption, the conditions for cooperative wage-led growth are:

$$
\frac{d\left(\pi^{a_{c}} u^{b_{c}}\right)}{d \pi}<0 \Leftrightarrow\left(b_{c} / a_{c}\right) \cdot \lambda \cdot \frac{\pi}{u}>1
$$

Similarly, we can assume that workers are interested in $(1-\pi)^{a_{w}} u^{b_{w}}$, instead of the special case Bhaduri and Marglin (1990) consider with $a_{w}=b_{w}=1$. In this case, the condition for cooperative profit-led growth is:

$$
\frac{d\left[(1-\pi)^{a_{w}} u^{b_{w}}\right]}{d \pi}>0 \Leftrightarrow\left(b_{w} / a_{w}\right) \cdot(-\lambda) \cdot \frac{\pi}{u}>\frac{\pi}{1-\pi}
$$

Equations (22) and (23) are telling us that the more workers and capitalists are interested in utilization relative to their share of income (the higher the $b / a$ ratios are), the more it is possible that the cooperative conditions are satisfied. In terms of figure 6 , the higher the $b / a$ ratios are, the longer the cooperative segments of the cycle last.

The preceding discussion also provides a link between shifting involvements and the economic basis of contesting political ideologies. This paper's model shows that the move between the profit- and wage-led regimes and their cooperative and conflictual subregimes provides the economic basic for shifts in ideologies. From that point of view we can understand within a unified framework the hegemony of social democracy in the early decades after WWII, the popularity of "trickle-down" economics in the early 1980s, and the increase in the popularity of social-democratic approaches today_at least in the United States and the United Kingdom. 


\section{CONCLUDING REMARKS}

The paper presented a model where distribution of income between capital and labor is determined by their involvement. As the involvement of the capitalists increases, or that of workers decreases, the profit share increases and vice versa. The shift in involvement is affected by its potential impact on economic activity and also has an unstable character: a higher income share will tend to further increase the involvement of a class, and thus further tilt distribution in its favor.

On the other hand, as the profit share increases, the economy becomes more wage led. As a result, we have a two-dimensional dynamic system. The system is unstable if the unstable behavior of distribution dominates. In the opposite case, the most possible configuration is predator-prey cycles in the $<$ profit share, wage-ledness $>$ space. These possibilities are useful when examining historical episodes in capitalist economies and the long-run dynamics of growth and distribution.

The paper also examines what Bhaduri and Marglin (1990) called "cooperative" and "conflictual" cases of profit- and wage-led growth. It demonstrates the likelihood that, in addition to the oscillations between wage- and profit-led periods, the economy may also move between the conflictual and cooperative subregimes. This provides a bridge between the economic basis for the changing popularity of contesting political ideologies and the shifting involvements.

Two final remarks related to potential future research paths are in order here. First, the variability of the growth regimes poses some challenges for their empirical estimation. In the existing empirical literature, the implicit or explicit running assumption is that the regime is constant over

a long period of time. ${ }^{19}$ An obvious advancement of this literature would be to take the changes in the effects of distribution on growth into account.

${ }^{19}$ See also Nikiforos $(2016 \mathrm{~b}, 402)$ for a related discussion. 
Second, the cycles described here also pose some interesting — albeit complex-questions related to comparative political economy. To begin with, the variability of the growth regimes emphasizes that each "variety of capitalism" is also changing and has its own subvarieties. Second, some open questions for future research include the comparative analysis of different capitalist economies. In a recent contribution, Baccaro and Pontusson (2016) introduce the importance of examining distribution-led growth regimes within a comparative political economy framework. If one would like to go a step further, we could ask questions like: How do the oscillations of involvements, growth, and distribution differ in different economies? How are the specific institutions in each economy related to the amplitude and the center of gravitation of these oscillations and how are these cycles different between the so-called liberal market economies, the mixed market economies, or the coordinated market economies? The discussion in the present paper focused on the historical experience of the US economy and provided only some hints for answering these questions, but more needs to be done. 


\section{REFERENCES}

Abowd, John M. 1989. "The effect of wage bargains on the stock market value of the firm." The American Economic Review 79 (4): 774-800.

Alvaredo, Facundo, Anthony B. Atkinson, Thomas Piketty, Emmanuel Saez, and Gabriel Zucman. 2016. "Distributional National Accounts (DINA) Guidelines: Concepts and Methods used in WID.world.” WID.world Working Paper No 2016/1. World Inequality Database.

Amadeo, Edward J. 1986. "The role of capacity utilization in the long period analysis." Political Economy 2 (2): 147-60.

Baccaro, Lucio, and Jonas Pontusson. 2016. "Rethinking comparative political economy: the growth model perspective.” Politics \& Society 44 (2): 175-207.

Baran, Paul, and Paul Sweezy. 1966. Monopoly Capital. New York: Monthly Review Press.

Bhaduri, Amit, and Stephen Marglin. 1990. "Unemployment and the Real Wage: The Economic Basis for Contesting Political Ideologies." Cambridge Journal of Economics 14 (4): 375-93.

Boyer, Robert. 2000. "Is a finance-led growth regime a viable alternative to Fordism? A preliminary analysis." Economy and Society 29 (1): 111-45.

Card, David. 1996. "The effect of unions on the structure of wages: A longitudinal analysis." Econometrica: Journal of the Econometric Society 64 (4): 957-79.

2001. "The effect of unions on wage inequality in the US labor market." Industrial and Labor Relations Review 54 (2): 296-315.

Center for Responsive Politics. 2019a. "Lobbying Database.” Data Retrieved January 25, 2019. https://www.opensecrets.org/lobby/.

. 2019b. "Politicians \& Elections." Data Retrieved January 25, 2019.

https://www.opensecrets.org/elections/.

Cohen, Lizabeth. 1991. Making a new deal: Industrial workers in Chicago, 1919-1939.

Cambridge, UK: Cambridge University Press.

Congressional Budget Office. 2017. "Distributional Effects of Changes in Taxes and Spending Under the Conference Agreement for H.R. 1, Legislation to Provide for Reconciliation Pursuant to Titles II and V of the Concurrent Resolution on the Budget for Fiscal Year 2018." Washington, DC: Congressional Budget Office.

Costantini, Orsola. 2018. "Invented in America: Birth and Evolution of the Cyclically Adjusted Budget Rule, 1933-61." History of Political Economy 50 (1): 83-117. 
Cynamon, Barry Z., and Steven M. Fazzari. 2015. "Household Income, Demand, and Saving: Deriving Macro Data with Micro Data Concepts." Review of Income and Wealth 63 (1).

Dharmapala, Dhammika, C. Fritz Foley, and Kristin J. Forbes. 2011. "Watch what I do, not what I say: The unintended consequences of the Homeland Investment Act." The Journal of Finance 66 (3): 753-87.

DiNardo, John, Nicole M. Fortin, and Thomas Lemieux. 1996. "Labor Market Institutions and the Distribution of Wages, 1973-1992: A Semiparametric Approach.” Econometrica 64 (5): $1001-44$.

DiNardo, John, and Kevin F. Hallock. 2002. "When unions 'mattered': The impact of strikes on financial markets, 1925-1937.” Industrial and Labor Relations Review 55 (2): 219-33.

Dutt, Amitava K. 1984. "Stagnation, income distribution and monopoly power." Cambridge Journal of Economics 8 (1): 25-40.

Edgecliffe-Johnson, Andrew, and Ed Crooks. 2018. "US tax cut said to have little impact on investment: Survey adds to the evidence that much of the windfall was used for share buybacks." Financial Times, October 29.

Epstein, Gerald A. 2005. Financialization and the world economy. Northampton, MA: Edward Elgar Publishing.

Farber, H. S. 2005. "Nonunion wage rates and the threat of unionization." International and Labor Relations Review 58 (3): 335-52.

Farber, Henry S., Daniel Herbst, Ilyana Kuziemko, and Suresh Naidu. 2018. "Unions and Inequality Over the Twentieth Century: New Evidence from Survey Data.” NBER Working Paper No. 24587. Cambridge, MA: National Bureau of Economic Research.

Ferguson, Thomas. 1995. Golden rule: The investment theory of party competition and the logic of money-driven political systems. Chicago: University of Chicago Press.

- 2014. "Big Money, Mass Media, and the Polarization of Congress." In Polarized Politics: The Impact of Divsiveness in the US Political System, edited by William J. Crotty. Boulder, CO: Lynne Rienner Books.

Ferguson, Thomas, Paul Jorgensen, and Jie Chen. 2016. "How Money Drives US Congressional Elections." Institute for New Economic Thinking Working Paper No. 48. New York: Institute for New Economic Thinking.

- 2017. "Fifty Shades of Green: High Finance, Political Money, and the U.S. Congress." Roosevelt Institute Report. New York: Roosevelt Institute. 
Firpo, Sergio, Nicole M. Fortin, and Thomas Lemieux. 2009. "Unconditional quantile regressions." Econometrica 77 (3): 953-73.

Galbraith, James K. 2012. Inequality and Instability: A Study of the World Economy Just Before the Great Crisis. New York: Oxford University Press.

Goodwin, R. M. 1967. “A Growth Cycle.” In Socialism, Capitalism and Economic Growth, edited by Charles H. Feinstein, 54-58. Cambridge, UK: Cambridge University Press.

Hacker, Jacob S., and Paul Pierson. 2010. Winner-take-all politics: How Washington made the rich richer-and turned its back on the middle class. New York: Simon \& Schuster.

Helleiner, E. 1996. States and the Reemergence of Global Finance: From Bretton Woods to the 1990s. Ithaca, NY: Cornell University Press.

Hirsch, Barry T., and David A. Macpherson. 2003. "Union membership and coverage database from the current population survey: Note." ILR Review 56 (2): 349-54.

Hirschman, Albert O. 2002 [1982]. Shifting Involvements: Private Interest and Public Action. 20th anniversary. Eliot Janeway Lectures on Historical Economics. Princeton, NJ: Princeton University Press.

Hobsbawm, Eric J. 1996 [1962]. The Age of Revolution 1789-1848. New York: Vintage Books. 1996 [1975]. The Age of Capital 1848-1875. New York: Vintage Books.

Kalecki, Michał. 1937. “The Principle of Increasing Risk.” Economica 4 (16): 440-47.

—. 1943. "Political Aspects of Full Employment." The Political Quarterly 14 (4): 322-30.

Keynes, John Maynard. 2013 [1936]. The General Theory of Employment, Interest and Money. Edited by Elizabeth Johnson and Donald Moggridge. The Collected Writings of John Maynard Keynes, Volume VII. Cambridge University Press.

Kurz, Heinz. 1990. "Technical Change, Growth and Distribution.” In Capital Distribution and Effective Demand: Studies in the Classical Approach to Economic Theory, edited by Heinz Kurz, 210-39. Cambridge, MA: Basil Blackwell.

Kuznets, Simon. 1955. "Economic Growth and Income Inequality." American Economic Review 45 (1): 1-28.

Lazonick, William. 2014. "Profits without prosperity." Harvard Business Review 92 (9): 46-55. 
Lazonick, William. 2015. "Stock buybacks: From retain-and-reinvest to downsize-and-distribute." Center for Effective Public Management of Brookings Institution Report. Washington, DC: Brookings Institution.

Lazonick, William, and Mary O’Sullivan. 2000. "Maximizing shareholder value: a new ideology for corporate governance." Economy and Society 29 (1): 13-35.

Lee, David S., and Alexandre Mas. 2012. "Long-run impacts of unions on firms: New evidence from financial markets, 1961-1999." The Quarterly Journal of Economics 127 (1): 333-78.

Leighley, Jan E., and Jonathan Nagler. 2007. "Unions, voter turnout, and class bias in the US electorate, 1964-2004." The Journal of Politics 69 (2): 430-41.

Lotka, Alfred J. 1910. "Contribution to the Theory of Periodic Reaction." Journal of Physical Chemistry A 14 (3): 271-74.

Maertens, Eppo. 2008. “Polanyi's Double Movement: A Critical Reappraisal.” Social Thought \& Research 29:129-53.

Marglin, Stephen. 2017. "Wages, prices, and employment in a Keynesian long run." Review of Keynesian Economics 5 (3): 360-425.

Marglin, Stephen, and Amit Bhaduri. 1990. "Profit Squeeze and Keynesian Theory." In The Golden Age of Capitalism: Reinterpreting the Postwar Experience, edited by Stephen Marglin and Juliet Schor, 153-86. Oxford: Clarendon Press.

Mason, Josh W. 2015. "Disgorge the cash: the disconnect between corporate borrowing and investment.” Roosevelt Institute Report. New York: Roosevelt Institute.

Minsky, Hyman. 1986. Stabilizing an Unstable Economy. New Haven, CT: Yale University Press. Myrdal, Gunnar. 1957. Economic Theory and Under-developed Regions. London: G. Duckworth.

National Association for Business Economics [NABE]. 2018. NABE Business Conditions Survey. National Association for Business Economics, October.

Nikiforos, Michalis. 2016a. "A nonbehavioral theory of saving." Journal of Post Keynesian Economics 39 (4): 562-92.

- 2016b. "Distribution-led growth in the long run." Review of Keynesian Economics 4 (4): 391-408.

Nikiforos, Michalis, and Gennaro Zezza. 2017. “The Trump Effect: Is This Time Different?” Levy Institute Strategic Analysis. Annandale-on-Hudson, NY: Levy Economics Institute of Bard College (April). 
Nikiforos, Michalis, and Gennaro Zezza. 2018. “'America First,' Fiscal Policy, and Financial Stability.” Levy Institute Strategic Analysis. Annandale-on-Hudson, NY: Levy Economics Institute of Bard College (April).

Orhangazi, Özgür. 2008. "Financialisation and capital accumulation in the non-financial corporate sector: A theoretical and empirical investigation on the US economy: 1973-2003." Cambridge Journal of Economics 32 (6): 863-86.

Phillips-Fein, Kim. 2009. Invisible hands: The making of the conservative movement from the New Deal to Reagan. New York: W. W. Norton.

Piketty, Thomas. 2014. Capital in the Twenty-First Century. Cambridge, MA: Harvard University Press.

Piketty, Thomas, and Emmanuel Saez. 2003. "Income inequality in the United States, 1913-1998." The Quarterly Journal of Economics 118 (1): 1-41.

Polanyi, Karl. 2001 [1944]. The Great Transformation: The Political and Economic Origins of Our Time. Boston: Beacon Press.

Ramsey, Frank P. 1928. “A Mathematical Theory of Saving.” The Economic Journal 38 (152): 543-59.

Rowthorn, Robert. 1981. "Demand Real Wages and Economic Growth.” Thames Papers in Political Economy. London: Thames Polytechnic.

Samuelson, Paul A. 1939. "A Synthesis of the Principle of Acceleration and the Multiplier." Journal of Political Economy 47 (6): 786-97.

Sánchez, Juan M., and Emircan Yurdagul. 2013. "Why Are Corporations Holding So Much Cash?” The Regional Economist, Federal Reserve Bank of St. Louis 21 (1): 4-8.

Silver, Beverly J., and Giovanni Arrighi. 2003. "Polanyi's 'double movement': The Belle Époques of British and US hegemony compared.” Politics \& Society 31 (2): 325-55.

Smolyansky, Michael, Gustavo Suarez, and Alexandra Tabova. 2018. 'U.S. Corporations' Repatriation of Offshore Profits.” FEDS Notes, September 4.

Soskice, David W., and Peter A. Hall. 2001. Varieties of capitalism: The institutional foundations of comparative advantage. Oxford: Oxford University Press.

Steindl, Joseph. 1952. Maturity and Stagnation in American Capitalism. Oxford: Basil Blackwell.

Stockhammer, Engelbert. 2004. "Financialisation and the slowdown of accumulation." Cambridge Journal of Economics 28 (5): 719-41. 
Tax Policy Center. 2017. "Distributional analysis of the conference agreement for the Tax Cuts and Jobs Act." Urban Institute-Brookings Institution Report. Washington, DC: Brookings Institution.

Taylor, Lance. 1983. Structuralist Macroeconomics. New York: Basil Books. 2004. Reconstructing Macroeconomics: Structuralist Proposals and Critiques of the Mainstream. Cambridge, MA: Harvard University Press.

The Campaign Finance Institute. 2019. "Number Political Action Committees Making Contributions to Candidates, 1976-2016.” Data Retrieved January 25, 2019. http://www.cfinst.org/pdf/vital/VitalStats_t9.pdf.

Vogel, David. 1989. Fluctuating Fortunes: The Political Power of Business in America. New York: Basic Books.

Volterra, Vito. 1931. "Variations and fluctuations of the number of individuals in animal species living together.” In Animal Ecology, edited by Royal N. Chapman. New York: McGraw-Hill.

Wolff, Edward N. 2017. A Century of Wealth in America. Cambridge, MA: Harvard University Press. 